\title{
Impact of Foreign Direct Investment in Indian Economic Development
}

\author{
G. Uppili Srinivasan, V. Anandavel
}

\begin{abstract}
Foreign direct investment (FDI) is always shows good impact in the growth of Indian economy and Foreign Direct Investment is the wonderful weapon device in the hands of Government of India. Foreign Direct Investment (FDI) plays vital role in an Indian economy. The new economic policy of liberalization, privatization and globalization pointed out in 1991 induced the policy of foreign direct investment. Hence the foreign direct investment is an inevitable one in our economy. FDI plays a multifaceted role in the overall development of any economy. FDI is often preferred over Foreign Institutional Investments (FII) as it considered to be the most beneficial form of foreign investment in an economy. FDI plays a multifaceted role in the complete development of any economy. It provides a new source for capital, can lead to technological up gradation, skill enhancement and allocate efficiency effects. While FDI is forecast to create clear impact on the economy, it has also contributed in certain adverse impact on Indian economy during the past few years. The present study is organized to study the correlation and investigate the impact of FDI on Indian economy. The flow of FDI for the past 15 years was taken for study (2003-2018). The consequences were studied by testing the correlation with the country's GDP and Stock Market Indices. Sensex and Nifty were calculated as the authenticated representative of Indian Stock Market. The study concludes that flow of FDI into the country plays a dominant role in deciding the stock market movements.
\end{abstract}

Keywords : FDI, Indian Economic Development, Sensex, Nifty.

\section{INTRODUCTION}

Foreign direct investment (FDI) is always shows good impact in the growth of Indian economy and Foreign Direct Investment is the wonderful weapon device in the hands of Government of India. Foreign Direct Investment (FDI) plays vital role in an Indian economy. The new economic policy of liberalization, privatization and globalization pointed out in 1991 induced the policy of foreign direct investment. Hence the foreign direct investment is an inevitable one in our economy. FDI plays a multifaceted role in the overall development of any economy. FDI is often preferred over Foreign Institutional Investments (FII) as it considered to be the most beneficial form of foreign investment in an economy. FDI plays a multifaceted role in the complete development of any economy. It provides a new source for capital, can lead to technological up gradation, skill enhancement and

Revised Manuscript Received on September 25, 2019

Dr. G.Uppili Srinivasan, Assistant Professor - II, Exam Wing, SASTRA Deemed University, Thanjavur

Dr. V.Anandavel, Assistant Professor, School of Management Studies, Kongu Engineering College, Perundurai allocate efficiency effects. While FDI is forecast to create clear impact on the economy, it has also contributed in certain adverse impact on Indian economy during the past few years. The present study is organized to study the correlation and investigate the impact of FDI on Indian economy. The flow of FDI for the past 15 years was taken for study (2003-2018). The consequences were studied by testing the correlation with the country's GDP and Stock Market Indices. Sensex and Nifty were calculated as the authenticated representative of Indian Stock Market. The study concludes that flow of FDI into the country plays a dominant role in deciding the stock market movements.

\section{REVIEW OF LITERATURE}

Narayanamurthy et al. (2010) examined the factors determining FDI inflows of developed countries during the period 1975 to 2007. Panel data analysis was used as a tool for the analysis. It was concluded from the results of the study that the selected variables Market size, Labour cost, Infrastructure, Currency value and Gross Capital formation are important determinants of FDI inflows of BRICS countries in terms of their potential. The stability of economic development and growth (measured by inflation rate and Industrial production respectively), business openness (measured by the ratio of total trade to GDP) was found to be the insignificant determinants of FDI inflows of the developed countries.

Chaturvedi (2011) explored the sector wise distribution of FDI in order to know the dominating sector which has attracted the major share of FDI in India and to find out the correlation between FDI and Economic Development. It revealed that there is high degree of significance between FDI and economic development.

Anitha (2012) analysed the FDI inflow into India during the Post Liberalization period, and projected the trends of FDI inflow into the country for a period of five years from 2010-11 to 2014-15 using Autoregressive Integrated Moving Average (ARIMA) model. The various factors which influence the flow of FDI were examined, the causes for low inflow were identified and remedial measures to increase the

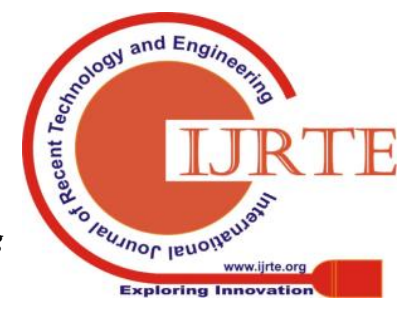


flow of FDI in India were suggested. The need to adopt innovative policies and good corporate governance practices at par with international standards, by the Government of India were identified as important factors, to attract sufficient foreign capital in different sectors of the economy. Goel et al. (2013) applied foreign direct investment model and economic growth model to study on Trends and Patterns of FDI in India and its Economic Growth using Total Trade as a percentage of GDP, Foreign Exchange Reserves as percentage of GDP, R\&D expenditure as percentage of GDP, ratio of external debts to export and Exchange rate for a period of 19912010. The results of Economic Growth Model and Foreign Direct Investment Model revealed that Trade GDP, Reserves GDP, and exhibit a positive relationship with FDI while R\&D, GDP and Exchange rate variables exhibit a negative relationship with FDI inflows. Hence, Trade GDP, Reserves GDP variables are the pull factors for FDI inflows to the country and R\&D, GDP and Exchange rate are deterrent forces for FDI inflows into the country. The study also reveals that FDI is a significant factor influencing the level of economic growth in India.

Singh, J., Chadha, S. and Sharma. A. (2014) in their study on analysing the impact of FDI on the economic growth of post communism transition economies concluded that FDI significantly and positively influence the economic growth of host countries. From this study the authors found out that FDI is positively correlated with an increase in a specific region's growth rate. The results finally show well-developed financial and institutional sectors are the vital sources of GDP growth and FDI inflows.

Parashar (2015) investigated the determining factors of foreign direct investment (FDI) inflow in both China and India from 1980 to 2013 using econometric modelling. Tools Linear regression analysis of time series data was done for 34 years to compute the results. Market size, infrastructure, and opportunity cost for investors, trade openness, growth rate, policy changes, and inflation were assumed as the determinants' macroeconomic indicators. To obtain the regression results both ordinary least squares analysis and partial least squares analysis approaches were applied The analysis revealed that, for both countries, market size was an important factor. Also, in the case of China, lower wage rates played an important role in attracting FDI, while in India; it is policy reforms that played a crucial role in attracting FDI.

Saini and Singhania (2017) investigated the potential determinants of FDI in developed and developing countries based on panel data analysis using static and dynamic modelling for 20 countries (11 developed and 9 developing), over the period 2004-2013. The analysis of the result shows that the internal and external factors play a significant role in shaping the trends of foreign capital inflows.

\section{THE OBJECTIVE OF THE STUDY}

1. To study the present status of FDI in the last fifteen years.

2. To analyse the impact of FDI in Indian economic growth and development

\section{SCOPE OF THE STUDY}

The present study deals only FDI inflows as well as impact in the economic development of country for the last fifteen years. To analyse the relationship of FDI and the stock market movement NIFTY and Sensex were selected for the study. The flow of FDI trends and impact on country's economic growth is evaluated in the study.

\section{DATA COLLECTION}

This study is based on secondary data. Data have been collected from various sources including RBI bulletins, Economic Survey Reports, NSE India and BSE India Websites and also from various publications of Ministry of Commerce. This study considers only last 15 years data i.e from 2003-04 to 2017-18. The Values of FDI, GDP, NIFTY and SENSEX have been averaged to get the most appropriate representation on an annual basis in case of stock market movements.

\section{ANALYSIS AND INTERPRETATION}

Table -1 shows the inflows of FDI and increasing of GDP during 2003-04 to 2017-18

\begin{tabular}{|c|c|c|c|c|}
\hline YEAR & $\begin{array}{c}\text { FDI } \\
\text { (US } \\
\mathbf{\$} \\
\text { Million) }\end{array}$ & $\begin{array}{c}\text { GDP(US\$ } \\
\text { Million) }\end{array}$ & NIFTY & SENSEX \\
\hline $2003-04$ & 4029 & 476.6 & 1333.35 & 3877.55 \\
\hline $2004-05$ & 6130 & 493.9 & 1060.75 & 3388.59 \\
\hline $2005-06$ & 5,035 & 523.7 & & 3352.77 \\
\hline $2006-07$ & 4,322 & 618.3 & 1778.55 & 5437.05 \\
\hline $2007-08$ & 6,051 & 721.5 & 2026.85 & 6233.54 \\
\hline $2008-09$ & 8,961 & 834.2 & 2835.25 & 9346.24 \\
\hline $2009-10$ & 22,826 & 949.1 & 3974.25 & 13731.09 \\
\hline $2010-01$ & 34,843 & 1238.7 & 5858.35 & 20286.99 \\
\hline $2011-12$ & 41,873 & 1224.1 & 2981.2 & 10076.43 \\
\hline $2012-13$ & 37,745 & 1365.4 & 5169.45 & 17401.56 \\
\hline $2013-14$ & 34,847 & 1708.5 & 6101.85 & 19242.36 \\
\hline $2014-15$ & 46,556 & 1835.8 & 4866.7 & 16488.24 \\
\hline $2015-16$ & 36,860 & 1831.7 & 5855.75 & 19426.71 \\
\hline $2016-17$ & 24,824 & 1861.8 & 6307.9 & 21032.71 \\
\hline $2017-18$ & 32,628 & 2066.9 & 8102.1 & 27507.54 \\
\hline S & & \multicolumn{2}{|c}{} \\
\hline
\end{tabular}

Source: Statistics Time.com

The Table - 1 shows the inflows fluctuations in terms of positive and negative variations in foreign direct investment during the study period. On the 
other hand GDP shows the increasing level during the study period. During the study period the following years were shows the variations percentages in FDI i.e. 2006-07 (0.85), 20212-13 (0.90), 2013-14 (0.92), 2015-16 (0.79) and 2016-17 (0.67). The percentages are low in the particular

Table -2 shows the statistics of summary of FDI, GDP, NIFTY \& SENSEX

\begin{tabular}{|l|r|r|r|r|}
\hline & \multicolumn{1}{|c|}{ FDI } & \multicolumn{1}{l|}{ GDP } & \multicolumn{1}{l|}{ NIFTY } & \multicolumn{1}{l|}{ SENSEX } \\
\hline Mean & 22117.3 & 1691.6 & 6237.2 & 16653.9 \\
\hline 5\% Trimmed Mean & 110586.5 & 7653.4 & 4176.1 & 12357.6 \\
\hline Median & 4613.2 & 1914.3 & 5512.6 & 19617.5 \\
\hline Variance & 117613186.4 & 164453.7 & 2504171.3 & 26337476.9 \\
\hline Std. Deviation & 10656.1 & 434.2 & 1715.3 & 5327.5 \\
\hline Minimum & 7796.0 & 817.2 & 2637.2 & 9247.2 \\
\hline Maximum & 36687.0 & 2084.9 & 8102.100 & 26432.5 \\
\hline Range & 31497.0 & 1247.7 & 5367.8 & 18434.3 \\
\hline Interquartile Range & 14657.5 & 674.9 & 2354.3 & 7644.9 \\
\hline Skewness & -1.084 & -0.264 & 0.034 & 0.192 \\
\hline Kurtosis & 1.345 & -1.372 & -0.232 & 0.264 \\
\hline
\end{tabular}

Source: Computed Data

Table -3 Correlation coefficient of FDI, GDP, NIFTY \& SENSEX

\begin{tabular}{|l|rr|c|c|}
\hline & FDI $\quad$ GDP & NIFTY & SENSEX \\
\hline FDI & 1 & & \\
\hline GDP & $.923^{* *}$ & 1 & & \\
\hline NIFTY & $.772^{* *}$ & $.946^{* *}$ & 1 & 1 \\
\hline SENSEX & $.823^{* *}$ & $.946^{* *}$ & $.978^{* *}$ & \\
\hline
\end{tabular}

**. Correlation is significant at the 0.01 level (2- tailed)

From the Table $-2 \& 3$ shows to find out the relationship of variables of FDI and BSE Sensex, FDI and GDP and FDI and NSE NIFTY correlation was applied. The result shows strong positive correlation between the FDI and BSE Sensex, FDI and GDP and FDI and NSE NIFTY during the study period.

\section{FINDINGS OF THE STUDY}

- The FDI inflows in to the country have shown an increasing \& decreasing trend during the study period 2003-04 to 2017-18.

- The analysis shows strong positive correlation between FDI and GDP growth and development of the country

- From the analysis highly positive correlation have been found between FDI and BSE Sensex movements

- The result shows highly positive correlation between FDI and NSE Nifty movements.

The analysis of the statistical results concluded that GDP, stock market movements were dependent to the extend of the FDI inflows, growth and development of the country.

\section{CONCLUSION}

At present India is liberalizing the Foreign Direct Investment policy as much as possible. The analyses of the results have been encouraging. According to the latest period though many internal and external factors affect the FDI. On the other hand GDP is increased during the study period. 
Countries: A panel analysis", Int. Journal of Business Science and Applied Management, Vol. 5(3),

[8] Parashar,S.(2015)," Factors affecting FDI inflow in China and India", University of Alberta Research Experience.

[9] Saini, N. and Singhania, M. (2017), "Determinants of FDI in developed and developing countries: a quantitative analysis using GMM", Journal of Economic Studies, Vol. 45 No. 2, pp. 348-382.

[10] Singh, J., Chadha, S. and Sharma. A. (2014)," Role of Foreign Direct Investment in India: An Analytical Study", International Journal of Engineering and Science, Vol. 1(50), 34-42. 